\title{
PENGENDALIAN PERSEDIAN BAHAN BAKU SEMEN DENGAN PENDEKATAN JUST IN TIME (STUDI PADA PERUSAHAAN SEMEN PT. NHR)
}

\author{
Abdurrahman Faris Indriya Himawan \\ Departemen Manajemen, Unversitas Muhammadiyah Gresik \\ Gresik, Indonesia, faris@umg.ac.id
}

\begin{abstract}
Background - PT. NHR is one of the new arrivals in the world of the cement industry in Indonesia, which was founded in 2011. Increased efficiency can be done in various activities in the company, one of which is by controlling inventory properly. The method that can be used by companies to manage their inventory is the Just In Time method.

Diterima : 18 Juni 2020

Direview : 18 Juni 2020

Direvisi : 27 Juli 2020

Disetujui : 31 Juli 2020

Objective - This study aims to determine the factors that cause the accumulation of the main raw material for cement and to determine the implementation of Just In Time in the inventory of the main raw material for cement at PT. NHR.

Design / methodology / approach - The type used is the type of qualitative research. There are 2 (two) studies, namely, key informants are the Head of the Warehouse Department, the Head of the Warehouse Operational Shift, and the Head of the Production Department. While non-key informants are Warehouse Operational Shift Staff, amounting to 3 (people). Determination of the informants was chosen by purposive sampling.

Results and discussion - The results showed that the factors causing the accumulation of the main raw material for cement in PT. NHR, namely (1) Inaccurate measurement of the main raw material for cement, (2) Negligent and inaccurate workers (3) Weak visual control of workers in the field due to lack of labor, hot weather and declining health, (4) Purchase of raw materials main cement with large quantities.

Conclusion - Implementation of the Just In Time system at PT. NHR has indirectly been implemented but is still not optimal because in the process of purchasing the main raw materials, cement is carried out in large quantities or not in accordance with the company's production plans.
\end{abstract}

Keywords: inventory, raw, material, Just In Time,.

\begin{abstract}
ABSTRAK
Latar belakang - PT. NHR merupakan salah satu pendatang baru di dunia industri semen di Indonesia yang berdiri sejak tahun 2011. Peningkatan efisiensi dapat dilakukan dalam berbagai kegiatan di perusahaan, salah satunya dengan melakukan pengendalian persediaan dengan baik. Metode yang dapat digunakan oleh perusahaan untuk mengelola persediaan yang dimiliki, adalah metode Just In Time.

Tujuan - Penelitian ini bertujuan untuk mengetahui Faktor-faktor yang menyebabkan terjadinya penumpukan bahan baku utama semen dan untuk mengetahui implementasi Just In Time pada persediaan bahan baku utama semen di PT. NHR.

Desain/metodologi/ pendekatan - Jenis yang digunakan adalah jenis penelitian kualitatif. Penelitian ini terdapat 2 (dua) yaitu, informan kunci adalah Kepala Departemen Gudang, Kepala Shift Operasional Gudang, dan Kepala Departemen Produksi. Sedangkan informan non kunci adalah Staf Shift Operasional Gudang yang berjumlah 3 (orang). Penentuan informan dipilih secara purposive sampling.

Hasil dan pembahasan - Hasil penelitian menunjukan bahwa faktor penyebab terjadinya penumpukan bahan baku utama semen di PT. NHR yaitu (1) Kurang akuratnya alat ukur bahan baku utama semen, (2) Para pekerja lalai dan kurang teliti (3) Lemahnya kontrol visual para pekerja dilapangan karena kurangnya tenaga kerja, cuaca yang panas dan kesehatan menurun, (4) Pembelian bahan baku utama semen dengan jumlah besar.
\end{abstract}


Kesimpulan - Penerapan sistem Just In Time di PT. NHR secara tidak langsung sudah diterapkan tetapi masih kurang maksimal karena dalam proses pembelian bahan baku utama semen dilakukan dalam jumlah besar atau tidak sesuai dengan rencana produksi perusahaan.

Kata Kunci : Persediaan, bahan, baku, Just In Time

\section{PENDAHULUAN}

Pertumbuhan industri manufaktur setiap tahun semakin berkembang, salah satu sektor industri manufaktur yang cukup baik dicermati adalah sektor semen yang semakin meningkat. Menurut International Cement Review, konsumsi semen dunia diperkirakan akan terus mengalami pertumbuhan yang positif, hal ini didorong oleh kenaikan semen yang tinggi di beberapa negara berkembang di dunia. (World Cement Review dan Asosiasi Semen Indonesia, 2011). Indonesia merupakan salah satu negara berkembang yang mengalami pertumbuhan konsumsi semen, hal ini terjadi seiring dengan berjalannya proyek-proyek infrastruktur pemerintah yang tertunda pada awal tahun 2016 . Produksi semen juga terserap oleh pembangunan pembangkit listrik, proyek pemerintah dan pembangunan infrastruktur pedesaan. Pertumbuhan industri semen di Indonesia yang semakin meningkat, dapat dilihat dari data perkembangan industri semen realisasi tahun 2014 hingga. 2016 dan proyeksi hingga tahun 2020, pada gambar 1 berikut.

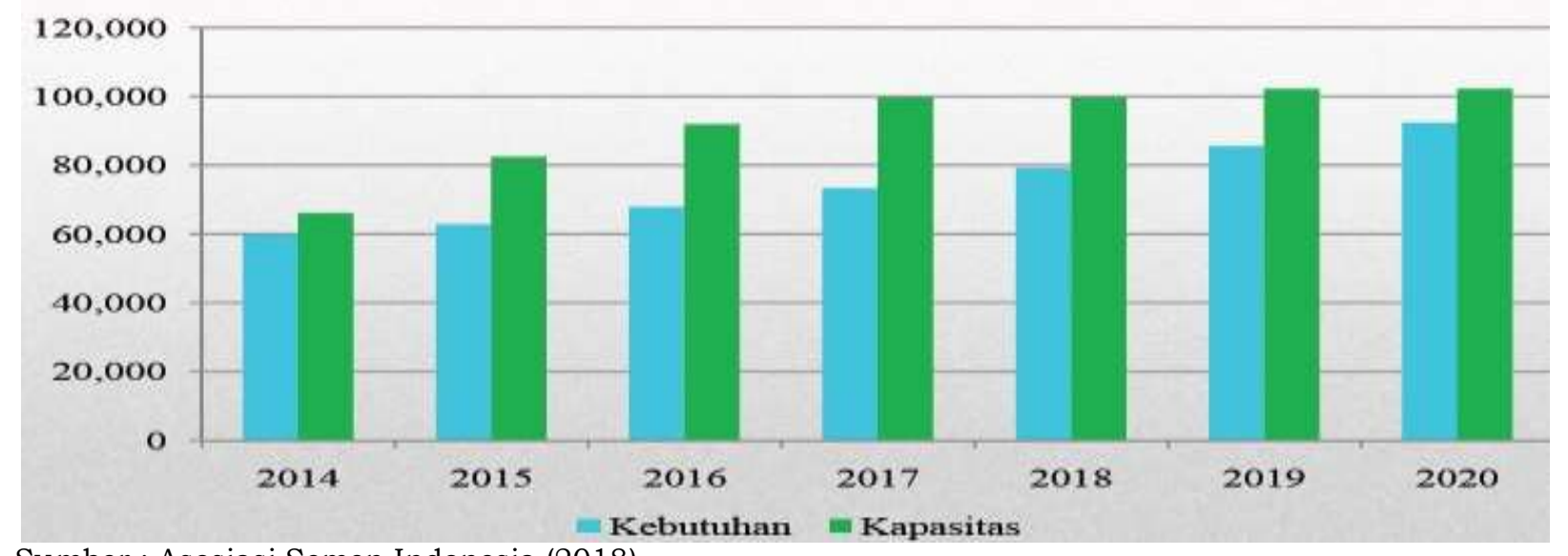

Sumber : Asosiasi Semen Indonesia (2018)

Gambar 1. Realisasi Tahun 2014 hingga 2016 dan Proyeksi hingga 2020 (dalam juta ton)

Saat ini Asosiasi Semen Indonesia mencatat terdapat sembilan produsen semen yang telah beroprasi di Indonesia, selain itu industri semen nasional juga akan mendapatkan tambahan kapasitas terpasang dari pabrik-pabrik pendatang di sejumlah wilayah Indonesia, diantaranya Semen 123 yang kapasitas produksinya mencapai 4,0 juta ton, Semen Anhuicoach dengan kapasitas 1,7 juta ton, Siam Sement 
1,8 juta ton, dan Semen Pan Asia 1,8 juta ton. (surya.co.id, 2016). Kehadiran pabrik semen baru akan terus memanaskan kompetisi pasar dengan pemain lama. Adanya persaingan yang sangat ketat antar perusahaan mendorong setiap perusahaan untuk menerapkan strategi secara tepat. Salah satu strategi yang dapat dilakukan adalah menciptakan produk yang lebih baik dari pesaingnya, hal ini dapat dicapai melalui peningkatan efisiensi perusahaan.

Peningkatan efisiensi dapat dilakukan dalam berbagai kegiatan di perusahaan. Salah satunya adalah dengan melakukan pengendalian persediaan dengan baik. Banyak metode yang dapat digunakan oleh perusahaan untuk mengelola persediaan yang dimiliki, salah satunya adalah metode Just In Time. Just In Time adalah memproduksi produk yang diperlukan, pada waktu dibutuhkan dalam jumlah sesuai kebutuhan pelanggan, pada setiap proses dalam sistem produksi dengan cara paling ekonomis melalui eliminasi pemborosan. (Sofyan, 2013).

PT. NHR salah satu pendatang baru di dunia industri semen di Indonesia yang berdiri sejak tahun 2011. Perusahaan ini memproduksi semen dengan merek dagang Semen 123. Pabrik pertama sekaligus pabrik pusatnya berlokasi di daerah Bayah, Banten Jawa Barat, dan pabrik yang lain sebagai cabang perusahaan berlokasi di Gresik, Jawa Timur yang baru berdiri pada tahun 2014. Sama halnya dengan perusahaan pusatnya PT. NHR dalam memproduksi semen, bahan baku yang digunakan terdiri dari dua jenis yaitu bahan baku utama dan bahan baku tambahan. Bahan baku utamanya yaitu material clinker dengan presentase pemakaian sebesar 71,0 $\%$, dan bahan baku tambahan terdiri dari tiga material yaitu limestone 14,0\%, trass 13,0 \% dan gypsum 2,0\%.

Pentingnya bahan baku utama dalam suatu proses produksi membuat PT. NHR yang masih terbilang baru tersebut, melakukan usaha monitoring dan menentukan komposisi bahan yang optimal untuk menunjang kelancaran kegiatan perusahaannya. Persediaan bahan baku utama semen yaitu material clinker oleh PT. NHR dilakukan dengan menyimpan bahan baku dalam jumlah yang banyak.

Berdasarkan Tabel 1 Persedian Bahan Baku Clinker, dapat dilihat bahwa pengendalian persediaan yang dilakukan oleh perusahaan menghasilkan sisa bahan baku atau stok material dalam jumlah banyak pada akhir bulan. Berdasarkan uraian dari latar belakang tersebut maka permasalahan yang akan dikemukakan dalam penelitian ini adalah (1) Apa saja faktor-faktor yang menyebabkan terjadinya penumpukan bahan baku utama semen di PT. NHR dan (2) Bagaimana implementasi Just In Time pada persediaan bahan baku utama semen di PT. NHR. 
Tabel 1

Persediaan Bahan Baku Clinker

\begin{tabular}{|c|c|c|c|}
\hline Bulan & $\begin{array}{c}\text { Penerimaan } \\
\text { Material } \\
\text { (Ton) }\end{array}$ & $\begin{array}{c}\text { Konsumsi } \\
\text { Clinker } \\
\text { (Ton) }\end{array}$ & $\begin{array}{l}\text { Stok Material } \\
\text { (Ton) }\end{array}$ \\
\hline Januari & $34.563,100$ & $26.804,200$ & $35.218,000$ \\
\hline Februari & $15.719,860$ & $22.500,000$ & $28.437,860$ \\
\hline Maret & $29.033,120$ & $38.434,680$ & $19.036,300$ \\
\hline April & $27.972,640$ & $29.568,860$ & $17.440,080$ \\
\hline Mei & $31.700,660$ & $28.304,501$ & $20,836,239$ \\
\hline Juni & $25.372,760$ & $36.420,370$ & $9.788,629$ \\
\hline Juli & $24.472,960$ & $21.447,790$ & $12.183,799$ \\
\hline Agustus & $34.560,570$ & $40.004,930$ & $7.369,439$ \\
\hline September & $51.237,180$ & $32.333,749$ & $26.272,870$ \\
\hline Total & $274.632,850$ & $275.819,080$ & $177.213,22$ \\
\hline
\end{tabular}

\section{TINJAUAN PUSTAKA}

\section{Pengendalian Persediaan}

Sediaan merupakan sumber daya ekonomi yang perlu diadakan dan disimpan untuk menunjang penyelesaian suatu produk. Sumber daya ekonomi dapat berupa kapasitas produksi, tenaga kerja, tenaga ahli, modal kerja, waktu yang tersedia dan bahan baku serta bahan penolong, namun dalam kajian saat ini, sedian dibatasi oleh material, produk sedang dalam proses pengerjaan, dan barang jadi, dengan demikian, persediaan adalah sumber daya ekonomi fisik yang perlu diadakan dan dipelihara untuk menunjang kelancaran produksi meliputi bahan baku, produk jadi, komponen rakitan, bahan pembantu, dan barang sedang dalam proses berjalan. (Murdifin \& Mahmud 2012).

Menurut Heizer \& Render (2014) mengatakan semua organisasi memiliki beberapa jenis sistem perencanaan dan sistem pengendalian persediaan, karena pada hakekatnya perencanaan dan pengendalian persediaan perlu diperhatikan, dari pengertian diatas dapat diartikan bahwa pengendalian persediaan merupakan hal yang perlu diperhatikan dimana untuk menjaga keseimbangan antara besarnya persediaan dengan biaya yang ditimbulkan dari persediaan.

\section{Tujuan Pengendalian Persediaan}

Menurut Agus Ristono (2009), ada 4 (empat) tujuan pengendalian persediaan, berikut penjelasannya:

1. Untuk dapat memenuhi kebutuhan atau permintaan konsumen dengan cepat.

2. Untuk menjaga kontinuitas produksi atau menjaga agar perusahaan tidak mengalami kehabisan persediaan yang berdampak terhentinya proses produksi.

3. Untuk mempertahankan dan mungkin meningkatkan penjualan dan laba.

4. Menjaga agar pembeliaan secara kecilkecilan dapat dihindari, karena dapat mengakibatkan ongkos pesan besar. 


\section{Just In Time}

Witjaksono (2013), Just in Time adalah suatu filosofi bisnis yang khusus membahas bagaimana mengurangi waktu produksi baik dalam proses manufaktur maupun proses non manufaktur. Selain itu dijelaskan pula oleh Murdifin \& Mahfud (2012), Just in Time merupakan strategi pengaturan sediaan yang menerapkan konsep untuk meningkatkan laba terhadap investasi dari sebuah usaha bisnis dengan mengurangi persediaan dan biaya-biaya yang terkait. Just in time pada dasarnya bermaksud menghasilkan unit yang diperlukan dalam jumlah yang diperlukan pada waktu diperlukan autonomasi (dalam bahasa jepang, "Ninbenno-aru Jidoka,") dengan longgar diterjemahkan sebagai pengendalian cacat secara otonom. (Monden 2000). Menurut Indrajid \& Pranoto (2003), tujuan penerapan Just In Time adalah :

1. Menciptakan fleksibilitas produk yang tinggi produksi, bersifat "sistem tarik"
2. Meningkatkan efisiensi proses produksi. Peningkatan efisiensi dapat dilakukan terutama melalui pengurangan persediaan barang.

3. Meningkatkan daya kompetisi. Hal ini adalah tujuan yang penting, yaitu suatu tujuan strategis, karena peningkatan efisiensi berarti penurunan biaya.

Menurut Heizer \& Render (2014), kemitraan Just In Time diantaranya :

1. Sedikit supplier

2. Jarak supplier dekat

3. Transaksi yang berulang kali dengan supplier yang sama.

Menurut Stevenson (2014), terdapat 5 (lima) elemen personel dan organisasi yang khusus penting dalam Just In Time, yaitu :

1. Pekerja sebagai asset

2. Pekerja yang dilatih silang

3. Perbaikan secara kontinu

Perbandingan manufaktur Just In Time dengan manufaktur Tradisional menurut Supriyono (2002) tertampil pada tabel 2.

Tabel 2

Perbedaan Metode Just In Time dan Tradisional

\begin{tabular}{clll} 
No. & \multicolumn{1}{c}{ Faktor Pembeda } & \multicolumn{1}{c}{ Just In Time } & \multicolumn{1}{c}{ Tradisional } \\
1. & Karakteritis & Pull-through system & Push-through system \\
2. & Kuantitas persediaan & Sedikit & Banyak \\
3. & Struktur manufaktur & Sel manufaktur & Sruktur departemen \\
4. & Kualifikasi tenaga kerja & Multidisiplin & Spesialis \\
5. & Kebijakan kualitas & Pengendalian mutu & Toleransi produk cacat \\
6. & Fasilitas jasa & Tersebar & Terpusat \\
\hline \multicolumn{2}{l}{ Sumber : Supriyono, $(2002 ; 255)$} &
\end{tabular}

Menurut Ristono (2009). Dasar yang diperlukan unuk kesuksesan sistem Just In Time adalah, (1) Eliminasi segala pemborosan, (2) Melibatkan tenaga kerja atau operator dalam pengambilan keputusan, dan (3) Partisipasi supplier

$$
\text { William \& Chuong }
$$
menambahkan pengembangan strategi 
untuk implementasi JIT juga harus didukung dengan pemeliharaan preventif, yaitu menekankan pemeliharaan perlengkapan dalam kondisi operasi yang baik dan menganti suku cadang yang mempunyai kecenderungan untuk rusak. Menurut Sofyan (2008), fokus dari langkahlangkah penerapan just in time terletak pada eliminasi pemborosani dan perbaikan terus menerus. Langkah- langkah penerapan just in time menurut hustanto sebagai berikut :

1. Membuat rencana kebutuhan bahan baku

(Rencana Produksi x Kebutuhan Bahan Baku)

2. Menghitung biaya pembelian bahan baku (Harga Bahan Baku x Bahan Baku Dibutuhkan)

3. Menghitung biaya pemesanan

Bahan Baku Dibutuhkan x Biaya Pesan Ukuran Lot Ekonomis

4. Menghitung biaya penyimpanan

$\frac{\text { Ukuran Lot Ekonomis x Biaya Simpan }}{2}$

5. Total biaya persedian

(Biaya Pembelian + Biaya Pemesanan + Biaya)

\section{METODE PENELITIAN}

Jenis penelitian yang digunakan adalah jenis penelitian kualitatif yaitu dengan menjelaskan dan menguraikan secara sistematis mengenai permasalahan yang akan diteliti. Selain itu alasan lainnya karena peneliti melihat sifat dari masalah yang diteliti berkembang secara alamiah sesuai kondisi dan situasi di lapangan.

Pendekatan penelitian yang digunakan oleh peneliti adalah pendekatan studi kasus. Alasan peneliti memilih studi kasus karena ingin mengetahui secara rinci dan menyeluruh terhadap kejadian atau kasus mengenai persediaan bahan baku utama semen di PT. NHR Gresik.

Unit analisis dalam penelitian ini adalah pengendalian persediaan bahan baku utama semen di PT. NHR yaitu material Clinker. Penelitian ini terdapat 2 (dua) informan yaitu, informan kunci dan informan non kunci, informan kunci adalah Kepala Departemen Gudang, Kepala Shift Operasional Gudang, dan Kepala Dept. Produksi, dan informan non kuncinya adalah Staff Shift Operasional Gudang yang berjumlah 3 orang. Teknik pengambilan data yang digunakan adalah dengan teknik wawancara, observasi dan dokumentasi.

\section{Teknik Analisis Data}

1. Menjawab rumusan masalah dan tujuan penelitian yang pertama. Analisis data yang yang digunakan adalah analisis fishbone diagram. Berikut penjelasannya:

a. Mengidentifikasi masalah.

Peneliti menuliskan permasalahan yang dihadapi, dengan membuat garis panah horizontal ke kanan yang akan menjadi tulang belakang.

b. Mengidentifikasi penyebab utama yang mempengaruhi hasil.

Peneliti akan menuliskan penyebab utama terjadinya penumpukan bahan baku utama semen di PT. NHR.

c. Mengidentifikasi faktor-faktor yang menjadi penyebab utama. 
Berdasarkan langkah kedua, penyebab yang mungkin telah terungkap, akan peneliti gambarkan berupa garis yang lebih kecil.

d. Langkah terkahir, peneliti akan menentukan penyebab yang paling dominan dan menentukan langkah perbaikan dari permasalahan yang terjadi.

2. Menjawab rumusan masalah dan tujuan penelitian yang kedua, antara lain dengan melakukan teknik analisis sebagai berikut :

a. Analisis Just In Time

langkah-langkah penerapan Just In Time pada persediaan untuk mengeliminasi pemborosan yaitu :

1) Membuat rencana kebutuhan bahan baku

2) Menghitung biaya pembelian bahan baku

3) Menghitung biaya pemesanan

4) Menghitung biaya penyimpanan

5) Total biaya persedian

Setelah melakukan tahapan diatas, selanjutnya peneliti akan menganalisis total biaya persediaan yang telah diketahui dengan mengunakan diagram pareto, untuk mengetahui selisih biaya total persediaan antara kondisi perusahaan dengan kondisi penerapan Just In Time.

b. Analisis Kualitatif Deskriptif

Analisis Kualitatif Deskriptif digunakan oleh peneliti untuk menganalisis variabel yang kedua dan ketiga dalam menjawab rumusan masalah yang kedua, analisis Kualitatif Deskriptif terdiri dari beberapa tahapan, yaitu: Reduksi data (data reduction), Penyajian data (data display), Kesimpulan dan Verifikasi

Kredibilitas merupakan istilah yang digunakan dalam penelitian kualitatif. Menurut Sugiyono (2010), dalam penelitian kualitatif pengecekan keabsahan data meliputi (1) uji kredibilitas data, (2) uji transferabilitas, (3) uji dependabilitas, (4) uji konfirmabilitas. Pengujian kredibilitas data dalam penelitian ini adalah triangulasi sumber dan teknik, menggunakan bahan referansi lain, meningkatkan ketekunan, dan Member check.

\section{HASIL DAN PEMBAHASAN}

PT. NHR merupakan salah satu pendatang baru di dunia industri semen di Indonesia yang berdiri sejak tahun 2011. Perusahaan ini memproduksi semen dengan merek dagang Semen 123. Pabrik pertama atau pabrik pusatnya berlokasi di daerah Bayah, Banten Jawa Barat, dan pabrik lainnya sebagai cabang perusahaan berlokasi di Gresik, Jawa Timur yang berdiri pada tahun 2014. Pabrik PT. NHR yang berlokasi di Gresik, Jawa Timur berada di lingkungan kawasan industri Maspion Gresik. Produk yang dihasilkan oleh PT. NHR yakni Portland Composite Cement (PCC). Merupakan semen ramah lingkungan serta dirancang untuk pembangunan bangunan umum, serta tersedia kemasan kantong $40 \mathrm{~kg}$ dan $50 \mathrm{~kg}$. 


\section{Analisis Fishbone}

Analisis data dalam penelitian ini yaitu dengan menggunakan fishbone diagram, analisis Just In Time, analisis diagram pareto dan analisis kualitatif deskriptif. Berikut analisis datanya :

1. Mengidentifikasi faktor-faktor penyebab menumpuknya bahan baku utama semen atau material clinker alat bantu yang digunakan dalam mengidentifikasi faktor - faktor penyebab menumpuknya bahan baku utama semen yaitu berupa fishbone diagram, yang diperoleh dari hasil wawancara kepada para informan.

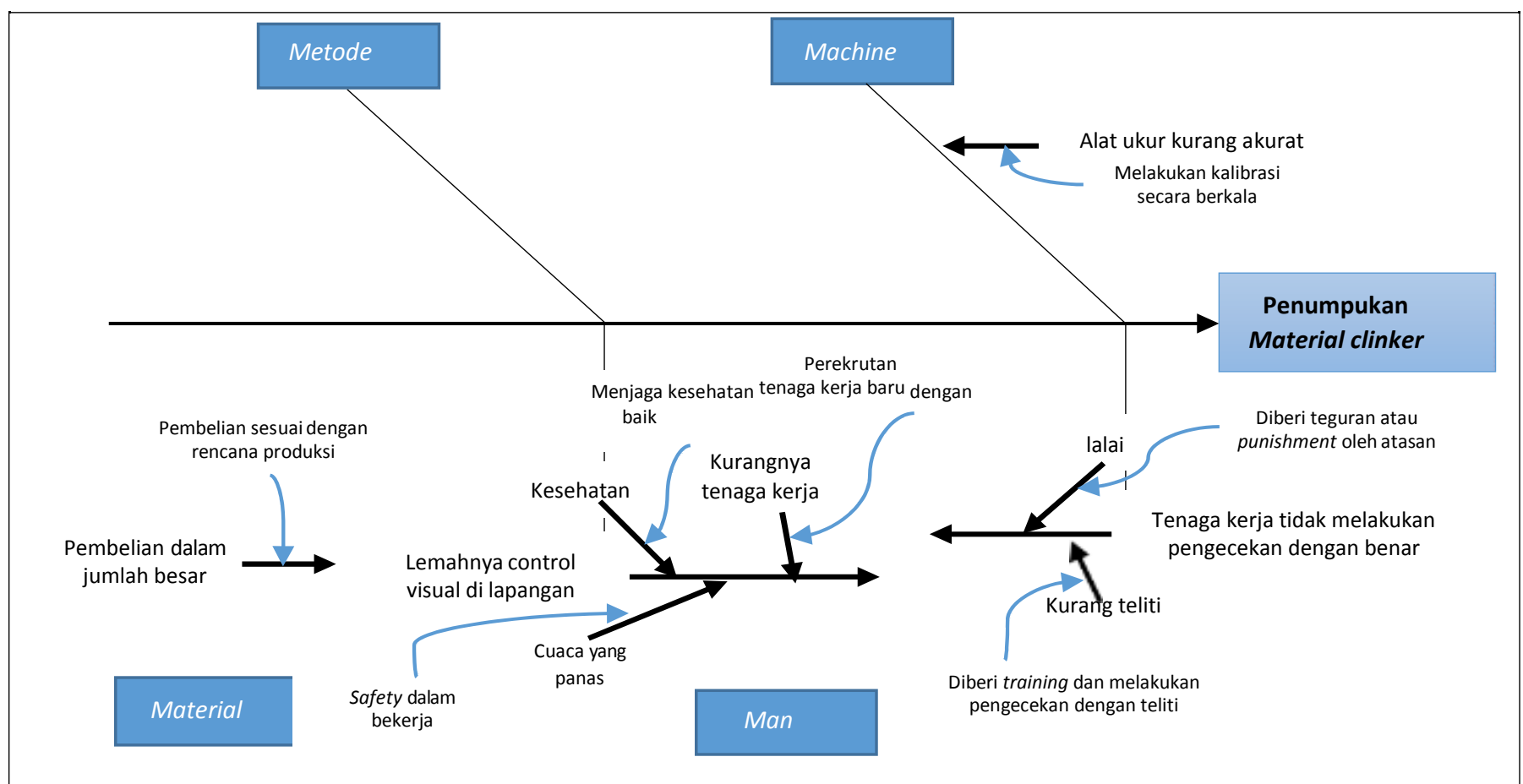

Keterangan :

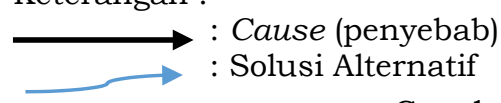

Gambar 2. Fishbone Diagram Penumpukan Material Clinker

Pada faktor mesin disebabkan karena kurang akuratnya alat ukur sebagai pengontrol persediaan bahan baku utama semen yang terletak di sillo clinker. Pengecekan dengan menggunakan alat ukur tersebut menunjukan jumlah yang tidak sesuai dengan stok fisik bahan baku utama semen, hal tersebut terjadi karena menurunnya kepasifan pada alat ukur, dimana pegas pada alat ukur tidak elastis, dan pada faktor metode atau cara, tidak mempengaruhi terjadinya penumpukan bahan baku utama semen.

Faktor manusia, tenaga kerja bagian staf shift operasional gudang yang tidak melakukan pengontrol persediaan bahan baku utama semen dengan benar karena lalai dan kurang teliti. Faktor manusia yang lain disebabkan karena lemahnya kontrol visual para pekerja dilapangan, hal tersebut dikarenakan kurangnya tenaga kerja, selain itu karena kondisi cuaca yang panas dan 
terkadang kesehatan pekerja menurun.

Pada faktor material salah satu penyebab menumpuknya bahan baku utama semen atau material clinker karena dalam pembelian bahan baku utama semen, perusahaan melakukan pembelian dalam jumlah besar atau tidak sesuai dengan rencana produksi perusahaan. Berdasarkan faktor-faktor penyebab terjadinya penumpukan bahan baku utama semen tersebut, faktor yang paling dominan adalah faktor material atau bahan baku, dimana perusahaan melakukan pembelian dalam jumlah besar atau tidak sesuai dengan rencana produksi perusahaan. Pembelian jumlah besar akan mengakibatkan kerugian bagi pihak perusahaan.

\section{Analisis Just in Time}

Analisis Penerapan Just In Time Pada persediaan bahan baku utama semen.
Setelah mengetahui faktor-faktor terjadinya penumpukan bahan baku utama semen selanjutnya akan di implementasikan dengan menggunakan Just In Time.

1. Eliminasi segala pemborosan

Pada tahap awal eleminasi segala pemborosan, perencanaan pembelian bahan baku harus disesuaikan dengan target produksi Berdasarkan penelitian di PT. NHR, 2.130 ton bahan baku utama semen menghasilkan 3.000 ton semen, dan kapasitas kebutuhan bahan baku dari setiap keluaran semen bersifat normal atau sama. Jadi untuk menghasilkan 1 ton semen membutuhkan 0,71 ton atau $71 \%$ bahan baku utama semen.

Maka dari itu perlu membuat perencanaan kebutuhan bahan baku sesuai dengan kebutuhan produksi semen dengan Just In Time (JIT) terlihat pada tabel 3.

Tabel 3

Rencana Kebutuhan Bahan Baku Utama Semen dengan Just In Time Pada PT. NHR

\begin{tabular}{|c|c|c|c|}
\hline Bulan & $\begin{array}{l}\text { Rencana Produksi } \\
\text { (ton) }\end{array}$ & $\begin{array}{c}\text { Kebutuhan Bahan } \\
\text { Baku } \\
\text { (1 ton semen) }\end{array}$ & $\begin{array}{l}\text { Kebutuhan Bahan baku } \\
\text { (ton) }\end{array}$ \\
\hline Januari & $37.752,394$ & 0,71 & $26.804,200$ \\
\hline Februari & $31.690,141$ & 0,71 & $22.500,000$ \\
\hline Maret & $54.133,352$ & 0,71 & $38.434,680$ \\
\hline April & $41.646,282$ & 0,71 & $29.568,860$ \\
\hline Mei & $39.865,494$ & 0,71 & $28.304,501$ \\
\hline Juni & $51.296,296$ & 0,71 & $36.420,370$ \\
\hline Juli & $30.208,155$ & 0,71 & $21.447,790$ \\
\hline Agustus & $56.344,972$ & 0,71 & $40.004,930$ \\
\hline September & $45.540,492$ & 0,71 & $32.333,749$ \\
\hline Total & $275.819,080$ & & \\
\hline
\end{tabular}

Penerapan Just in Time (JIT) pada perencanaan kebutuhan bahan baku utama semen pada bulan Januari sampai dengan bulan September 2016 dihasilkan sebanyak 275.819,080 ton. Kebutuhan bahan baku dengan sistem Just in Time menimbulkan 
efisiensi pada pembelian kebutuhan bahan baku oleh perusahaan sebanyak 302.091,950 ton, jumlah tersebut terlihat pada tabel 1 persediaan bahan baku clinker pada penerimaan material yang ditambah dengan stok persediaan di akhir bulan desember 2015. Selisih efiensi kebutuhan bahan baku yang direncanakan perusahaan dengan sistem Just in Time sebanyak $26.272,870$ ton.

Pada tahap selanjutnya menghitung biaya pembelian bahan baku utama semen. Berdasarkan penelitian di PT. NHR harga bahan baku utama semen seharga Rp. 540.000/ton, ditunjukkan pada tabel 4 . Berdasarkan penerapan Just In Time pada pembelian bahan baku utama semen bulan Januari sampai bulan September 2016 sebesar Rp.148.942.303.200. Pembelian bahan baku dengan Just In Time menimbulkan efisiensi pada pembelian bahan baku utama semen dibanding dengan yang dilakukan oleh perusahaan Rp. 163.129.653.000. Sehingga dari penerapan Just In Time, menimbulkan efisiensi pembelian sebesar Rp. 14.187.349.800.

Kemudian akan dilanjutkan ke proses pengiriman bahan baku oleh supplier pada proses pengiriman tersebut terdapat biaya pemesanan yang harus ditanggung oleh perusahaan, sebagai akibat adanya pemesanan persediaan bahan baku. Biaya pemesanan bahan baku utama semen di PT. NHR mencakup dua macam biaya, yaitu biaya telpon dan biaya pengiriman. Biaya pemesanan bahan baku utama semen atau material clinker di PT. NHR tersebut diasumsikan berjumlah Rp 110.500

Berdasarkan penerapan Just In Time pada biaya pemesanan persediaan bahan baku utama semen atau material clinker pada bulan januari sampai dengan bulan september 2016 sebesar Rp. 1.028.792,801, sedangkan biaya pemesanan persediaan bahan baku utama semen yang dilakukan perusahaan sebesar Rp. 1.028.793,108. Sehinggah dari penerapan Just In Time tidak menimbulkan pengaruh secara signifikan dalam mengurangi biaya pemesanan, tetapi disisi lain, akan ada biaya - biaya lain dari penerapan Just In Time yang menimbulkan keefisienan pada total biaya persediaan bahan baku utama semen.

Tahap selanjutnya, bahan baku utama semen yang sudah dikirim oleh supplier akan dibawa ke Dept. Gudang untuk disimpan. Biaya penyimpanan bahan baku utama semen tersebut terdiri dari biaya pemakaian listrik dan biaya kebersihan. Total biaya penyimpanan persediaan bahan baku utama semen diasumsikan sekitar 10\% dari harga bahan baku utama semen.

Berdasarkan penerapan Just in Time pada biaya penyimpanan persediaan bahan baku utama semen atau material clinker pada bulan januari sampai dengan bulan september 2016 sebesar Rp. 779.875.567. Biaya penyimpanan bahan baku dengan Just in Time menimbulkan efisiensi terhadap 
biaya produksi dari pada biaya penyimpanan yang dilakukan perusahaan sebesar Rp. 876.066.651. Sehingga dari penerapan JIT menimbulkan efiensi biaya penyimpanan persediaan bahan baku sebesar Rp. 96.191,084.

Langkah terakhir yaitu menentukan total biaya persediaan bahan baku yang dilakukan dengan menjumlahkan biaya pembelian, biaya pemesanan dan biaya penyimpanan, seperti terlihat pada tabel 5 .

Berdasarkan hasil perhitungan diatas, menunjukan bahwa penerapan JIT dapat menimbulkan efisiensi pada total biaya persediaan bahan baku utama semen per bulan sebesar Rp. 1.587.060.098. Perbandingan kondisi tersebut dapat dilihat pada gambar 3 diagram pareto.

Tabel 4

Bahan Baku Semen PT. NHR

\begin{tabular}{l|cccc} 
Material & $\begin{array}{c}\text { Kapasitas Gudang } \\
\text { (Ton) }\end{array}$ & $\begin{array}{c}\text { Lead Time } \\
\text { (hari) }\end{array}$ & $\begin{array}{c}\text { Harga } \\
\text { (Rp)/ton }\end{array}$ & $\begin{array}{c}\text { Presentase } \\
\text { Pemakaian } \\
\text { (\%) }\end{array}$ \\
Clinker & 50.000 & 3 & 540.000 & $71 \%$ \\
Limestone & 3.000 & 5 & 165.000 & $14 \%$ \\
Trass & 5.000 & 5 & 110.000 & $13 \%$ \\
Gypsum & 10.000 & 50 & 299.500 & $2 \%$ \\
Clinker & 50.000 & 3 & 540.000 & $71 \%$ \\
Limestone & 3.000 & 5 & 165.000 & $14 \%$ \\
\hline Sumber: PT. NHR (2016) & & &
\end{tabular}

Tabel 5

Total Biaya Persediaan Perusahaan dan Total Biaya Persediaan JIT Bahan Baku Utama Semen atau Material Clinker

\begin{tabular}{|c|c|c|}
\hline Uraian & Perusahaan & JIT \\
\hline $\begin{array}{l}\text { Biaya Pembelian : } \\
1 . \quad \text { Rp. } 540.000 \times 302.091,950 \text { ton }\end{array}$ & Rp. 163.129.653.000 & Rp. 148.942.303.200 \\
\hline
\end{tabular}

Biaya Pemesanan :

302.091,950 ton $\times$ Rp. 110.500

$32.446,913$ ton

$275.446,913$ ton $x$ Rp. 110.500

$29.625,021$ ton

$\begin{array}{ll}\text { Rp. } 1.028 .793,108 & \text { Rp. } 1.028 .792,801\end{array}$

Biaya Penyimpanan :

$\frac{32.446,913 \text { ton } x \text { Rp. } 54.000}{2}$

$\frac{29.625,021 \text { ton } \times 54.000}{2}$

$\begin{array}{ll}\text { Rp. } 876.066 .651 & \text { Rp. } 779.875 .567\end{array}$

Total biaya persediaan bulan januari hingga bulan September

Total Biaya Persediaan / Bulan

Sumber: data hasil penelitian (diolah)

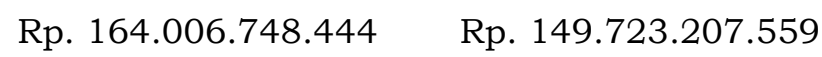

Rp. 18.222.972.049 Rp. 16.635.911.951 


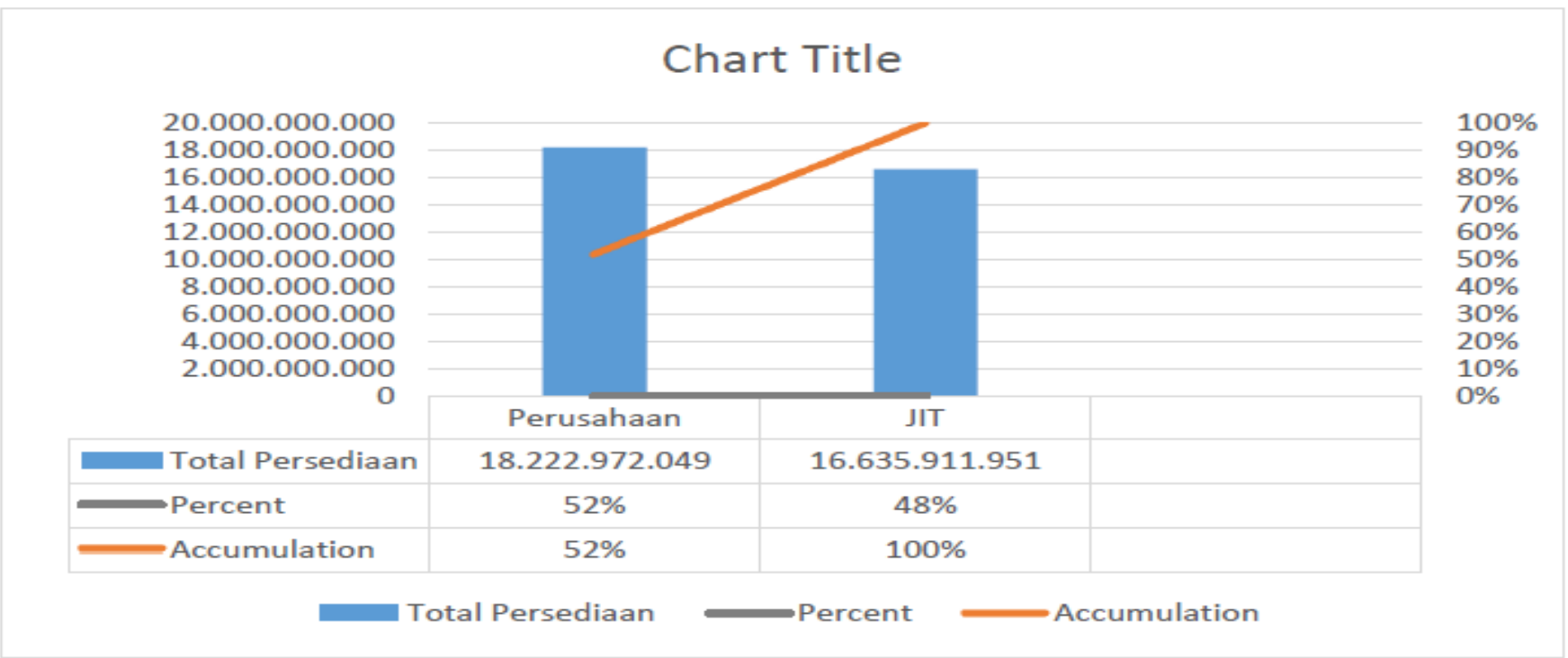

Gambar 3. Diagram Pareto Perbandingan Total Biaya Persediaan Perusahaan dengan JIT setiap bulannya.

2. Melibatkan tenaga kerja atau operator dalam pengambilan keputusan

Menurut pandangan Just In Time terdapat 3 (tiga) elemen personel atau tenaga kerja dalam pembentukan kesuksesan Just In Time (JIT), dan berikut penjelasannya :

a. Pekerja sebagai asset

Pekerja sebagai asset sebagai salah satu pembentuk kesuksesan Just In Time secara tidak langsung sudah dilakukan oleh PT. NHR, tetapi dalam hal pembagian tugas dan wewenang masih kurang maksimal, hal tersebut disebabkan karena kurangnya tenaga kerja di bagian staf shift operasional gudang, dalam proses pengendalian persediaan dengan just In Time pembagian tugas dan wewenang secara tepat dengan tenaga kerja memadai.

b. Pekerja yang dilatih silang

Pertukaran tugas terhadap sesama staf shift operasional gudang di NHR ternyata mendukung pembentukan kesuksesan Just In Time dimana pekerja dilatih secara silang, dengan begitu para pekerja akan mampu membantu satu sama lain ketika rekan kerja tidak hadir, atau rekan kerja kurang maksimal dalam menjalankan tugasnya karena kesehatan para pekerja menurun dan karena kondisi cuaca yang panas. Selain itu para pekerja harus selalu menjaga kesehatannya dengan memaksimalkan jam istirahat perusahaan dengan baik dan pekerja juga harus selalu safety dalam bekerja, sehinggah dalam kondisi cuaca apapun para pekerja bagian staf shift operasional gudang dapat bekerja secara maksimal.

c. Perbaikan secara kontinu

Perbaikan secara kontinu dengan melakukan pelatihan secara intesif 
kepada para karyawan dalam menyukseskan pelaksanaan Just In Time di PT. NHR Gresik saat ini masih belum dilakukan karena hanya ada petemuan kecil tanpa ada pelatihan secara khusus terhadap para karyawan. Salah satu faktor terjadinya penumpukan bahan baku utama semen atau material clinker dimana para pekerja tidak melakukan pengecekan pada persediaan bahan baku utama semen dengan benar karena lalai dan kurang teliti, perbaikan secara kontinu sebagai pembentuk kesuksesan Just In Time dapat diterapkan di PT. NHR Gresik dengan melakukan pelatihan atau training dan pengembagan kepada para pekerja bagian staf shift operasional gudang dan tentunya dengan persiapan dan perencanaan yang matang, sehinggah para pekerja akan lebih teliti dan tidak lalai dalam melakukan pekerjaannya.

Hubungan supplier bahan baku utama semen atau material clinker dengan perusahaan PT. NHR Gresik terjalin dengan sangat baik, sehinggah jika dilihat dari hubungan perusahaan dengan supplier tidak sampai mempengaruhi terjadinya penumpukan bahan baku utama semen atau material clinker, dikatakan demikian karena dalam proses pengiriman bahan baku utama semen, supplier selalu mengirim secara tepat waktu tidak terlambat ataupun tidak terlalu cepat dan sudah sesuai dengan
PO (pre order) yang telah disepakati oleh perusahaan dan supplier, dengan lead time atau jarak waktu antara waktu pemesanan sampai dengan bahan baku sampai di perusahaan selama 3 (tiga) hari.

Hubungan supplier dengan pemasok dalam just in time memiliki karakteritis kemitraan Just In Time sebagai berikut :

a. Sedikit supplier

supplier atau pemasok bahan baku utama semen atau material clinker di PT. NHR Gresik hanya berjumlah satu, yaitu PT. Holcim Indonesia yang berlokasi di daerah Tuban Jawa Timur. Pemilihan supplier atau pemasok yang hanya berjumlah satu tersebut oleh PT. NHR Gresik dilakukan dengan alasan kualitas bahan baku yang dibeli di PT. Holcim Indonesia memiliki kualitas bahan baku yang bagus dan bermutu tinggi di banding dengan membeli bahan baku dari supplier yang lain. Selain itu dapat mempermudah dalam pengontrolan pembelian bahan baku utama semen atau material clinker.

b. Jarak supplier dekat

Supplierbahan baku utama semen di PT. NHR adalah PT. Holcim Indonesia berlokasi di Tuban Jawa Timur. Sesuai dengan hasil pengamatan yang telah dilakukan oleh peneliti, lead time atau jarak waktu antara waktu pemesanan sampai dengan bahan baku sampai di perusahaan adalah 3 (tiga) hari. Lead time bahan baku utama semen tersebut 
terbilang sedikit dibandingkan dengan lead time bahan baku yang lain. Sedikitnya leat time bahan baku utama semen atau material clinker menunjukkan bahwa lokasi supplier perusahaan PT. NHR adalah dekat.

c. Transaksi yang berulang kali dengan pemasok yang sama.

Transaksi yang berulang kali dengan supplier yang sama sebagai salah satu karakteritis kemitraan just in time secara umum sudah bisa diterapkan di PT. NHR, dengan lokasi supplier yang dekat dan jumlah supplier yang hanya satu, perusahaan akan dapat melakukan pembelian secara Just In time yaitu pembelian dengan pengiriman secara berulang kali atau sesuai dengan rencana produksi perusahaan dengan perbaikan secara terus menerus. Sehingga terjadinya penumpukan bahan baku utama semen atau material clinker di PT. NHR yang disebabkan karena pembelian bahan baku kepada supplier dalam jumlah banyak dapat diatasi dengan baik.

\section{Pemeliharaan preventif}

Pemeliharaan pada mesin produksi di PT. NHR dilakukan secara rutin dengan melakukan pengecekan pada mesin sebelum melakukan proses produksi, sedangkan untuk pemeliharaan pada alat ukur yang terletak di sillo clinker sampai saat ini masih belum pernah dilakukan, sehinggah dalam pengontrolan persediaan bahan baku utama semen atau material clinker terkadang menunjukan jumlah yang tidak sesuai atau kurang akurat dengan stok fisik bahan baku utama semen.

Oleh karena itu, dalam mengatasi terjadinya bahan baku utama semen atau di PT. NHR yang disebabkan karena kurang akuratnya alat ukur sebagai pengontrol persediaan bahan baku utama semen yang terletak di sillo clinker juga diperlukan pemeliharaan prefentif dengan melakukan kalibrasi secara berkala pada alat ukur, yang secara umumnya dilakukan secara rutin setiap 6 bulan sekali agar dapat bekerja sesuai fungsinya.

\section{KESIMPULAN}

1. Faktor penyebab terjadinya penumpukan bahan baku utama semen, yaitu (a) Kurang akuratnya alat ukur bahan baku utama semen, (b) Para pekerja lalai dan kurang teliti (c) Lemahnya kontrol visual para pekerja dilapangan karena kurangnya tenaga kerja, kondisi cuaca yang panas dan kesehatan yang menurun, (d) Pembelian bahan baku utama semen dengan jumlah besar.

2. Hasil analisis penerapan Just In Time (JIT) dengan menggunakan langkah langkah dalam strategi Just In Time (JIT)

a. Implementasi Just in Time (JIT) secara tidak langsung sudah diterapkan di PT. NHR Gresik, tetapi dalam pelaksanaanya masih kurang maksimal karena dalam proses 
pembelian bahan baku utama semen atau material clinker dilakukan dalam jumlah besar atau tidak sesuai rencana produksi perusahaan, dan masih perlu dilakukan perbaikan secara terus menurus.

b. Eliminasi segala pemborosan sebagai langkah operasional pertama Just in Time pada persediaan bahan baku utama semen dalam memenuhi kebutuhan produksi telah menimbulkan penurunan total biaya persediaan bahan baku utama semen atau material clinker per bulan sebesar Rp. 1.587.060.098.

c. Analilsis diagram pareto, menunjukan bahwa penerapan Just In Time dalam mengeliminasi segala pemborosan memiliki prosentase yang lebih kecil yaitu 48\% dibanding dengan yang dilakukan perusahaan.

\section{IMPLIKASI PENELITIAN}

1. Perusahaan diharapkan dapat menghilangkan segala aktivitas yang tidak bernilai tambah dengan jalan tidak melakukan pembelian bahan baku utama semen dalam jumlah besar dengan menerapkan kebijaksanaan pembelian Just In Time, yaitu melakukan pembelian secara tepat waktu atau sesuai dengan rencana produksi perusahaan

2. Melakukan perhitungan jumlah kerugian biaya yang diakibatkan pembelian bahan baku dalam jumlah banyak, supaya kerugian timbul akan cepat terpantau dan cepat berfikir untuk memberikan solusi dalam mengatasi hal tersebut.

3. Memberikan pelatihan seacara intensif kepada para pekerja, khususnya para pekerja bagian staf shift operasional gudang, agar saat bekerja pekerja sudah memahami dan mengerti cara-cara bekerja yang baik dan tanggap dalam bekerja.

4. Sebaiknya tidak hanya mesin produksi yang mendapatkan perawatan secara rutin, tetapi alat ukur yang berada di sillo clinker juga harus dilakukan perawatan secara rutin setiap $6($ enam) bulan sekali agar dapat berjalan sesuai fungsinya.

\section{DAFTAR PUSTAKA}

Agus Ristono. 2009. Manajemen persediaan edisi 1, Yogyakarta: graha ilmu

Assauri, Sofyan. 2008. Manajemen Produksi dan Operasi, Lembaga Penerbit Faultas Ekonomi

Hamming, M dan Nurnajamuddin, M., 2012, Manajemen Produksi Modern (Edisi 2), Bumi Aksara, Jakarta.

Heizer, J, dan Barry R., 2014, Manajemen Operasi (Operations Manajemen), edisi 10, Salemba empat, Jakarta. 
Indrajid ER dan R Djokopranoto, 2003, Konsep Supply Chain Manajemen, Cetakan Kedua, PT. Grasindo, Jakarta.

Monden, Yusuhiro, 2000, Sistem Produksi Toyota, CV Teruana Grafica, Jakarta. Ristono, Agus, 2008, Manajemen Persediaan, Graha Ilmu, Yogyakarta.

Sofyan, Diana K., 2013, Perencanaan dan Pengendalia Produksi, Graha Ilmu, Yogyakarta

Stevenson, W.J dan Chuong, S.C, 2014, Manajemen Operasional Perpektif Asia, Salemba Empat, Jakarta.

Sugiyono, 2010, Memahami Penelitian Kualitatif, Alfabeta, Bandung.

Supriyono, "Pendekatan Just In Time", 2002., https://ejournal.stiesia.ac.id diakses 26 Desember 2016

Witjaksono, Armanto, 2013. Akuntasi Biaya (Edisi Revisi), Graha Ilmu, Yogyakarta.

World Cement Review dan ASI, 2011, "Kondisi Industri Semen." available online at: https://debudanabu.wordpress.com/2011/10/04/kondisi-industri-semen- di-dunia, diakses Oktober 2016.

2016, "Konsumsi Terus Meningkat Industri Semen Tumbuh". available online at : http://www.kemenperin.go.id/artikel/3612/Konsumsi- Terus-Meningkat,Industri-Semen-Tumbuh-16, diakses Desember 2016. 